\title{
PENGEMBANGAN MEDIA PEMBELAJARAN TILAWATIL QURAN BERBASIS VIDEO DENGAN MENERAPKAN CURVE AUDIO TRACKING
}

\author{
Ahmad Syawlana ${ }^{1}$, Prasetyo Wibowo Yunanto ${ }^{2}$, Z.E. Ferdi Fauzan Putra ${ }^{3}$ \\ ${ }^{1}$ Mahasiswa Prodi PendidikanTeknik Informatika dan Komputer, Teknik Elektro, FT - UNJ \\ ${ }^{2,3}$ Dosen Prodi Pendidikan Teknik Informatika dan Komputer, Teknik Elektro, FT - UNJ \\ 1ahmadsyawlana@gmail.com,${ }^{2}$ prasetyo.wy@gmail.com,$\underline{{ }^{3} \text { ze.ferdi@gmail.com }}$
}

\begin{abstract}
Abstrak
Al-Quran merupakan kitab suci bagi umat Islam yang sempurna dari segi kata maupun makna. Bacaan Al-Quran dengan nagham (lagu) dipelihara sejak zaman Rasulullah SAW sampai saat ini dan menjadi seni yang disebut Tilawatil Quran atau tilawah. Saat ini banyak lembaga pendidikan formal maupun non-formal yang memberikan ruang untuk mempelajari Al-Quran. Namun, tidak semua lembaga pendidikan memberikan pengajaran untuk tilawatil quran. Di Era Millenial ini, seharusnya teknologi dapat mempermudah pembelajaran tilawatil quran. Penelitian ini bertujuan untuk menghasilkan media pembelajaran tilawatil quran dengan menerapkan Curve Audio Tracking. Curve Audio Tracking akan memvisualisasikan irama nagham (lagu) yang dibacakan oleh Qari dalam bentuk kurva fluktuatif. Penelitian ini menggunakan metode Research \& Development dengan model pengembangan Multimedia Development Life Cycle (MDLC). Hasil penelitian ini menunjukkan media pembelajaran dengan menerapkan Curve Audio Tracking berhasil dikembangkan untuk mempelajari tilawatil quran dan mendapatkan skor yang termasuk dalam kategori Sangat Layak dengan skor 84,3\% untuk dikembangkan dan disebarluaskan. Curve Audio Tracking berhasil diterapkan pada media pembelajaran tilawatil quran dengan melakukan konversi suara menjadi keyframe.
\end{abstract}

Kata kunci : Al-quran, Tilawatil Quran, Tilawah, MTQ, Curve Audio Tracking

\section{Pendahuluan}

Al-Quran merupakan kitab yang sempurna dari segi kata maupun makna. Bahkan berkat keindahan dan keagungan Al-Quran, bacaan Al-Quran dengan nagham (lagu) pun dipelihara sejak zaman Rasulullah SAW, para sahabat, sampai para tabi'in. Perkembangan seni membaca Al-Quran dengan nagham (lagu) terus berkembang dan dianggap menjadi sebuah seni yang disebut seni membaca AlQuran atau tilawatil quran. Berkat kecintaan terhadap keindahan dan keagungan Al-Quran, umat Islam mengadakan event sebagai ajang kompetisi membaca Al-Quran yang disebut Musabaqah Tilawatil Quran (MTQ).

Saat ini banyak lembaga-lembaga pendidikan yang memberikan ruang untuk mempelajari AlQuran. Baik di lembaga pendidikan formal seperti di sekolah/madrasah maupun di lembaga pendidikan non formal. Namun, dalam perkembangannya sangat sedikit lembaga pembelajaran Al-Quran yang memberikan pengajaran tilawatil quran.

Pada survei yang saya lakukan terhadap 100 responden pada tanggal 29 Januari 2019, diketahui bahwa 33 orang mempelajari tilawatil quran melalui Internet, dan sebanyak 31 orang mempelajari tilawatil quran melalui orang-orang terdekat seperti orangtua, kerabat, dan sebagainya. Dari data tersebut dapat diketahui bahwa sebagian besar responden mempelajari tilawatil quran bukan melalui lembaga pendidikan Al-Quran.

Media yang digunakan ketika mereka mempelajari tilawatil quran adalah 45,8\% melalui Internet. Statistik ini menunjukkan bahwa perkembangan teknologi memiliki pengaruh yang sangat besar terhadap pembelajaran tilawatil quran. Aspek yang paling sulit dalam mempelajari tilawatil quran adalah irama nagham (lagu) yaitu sebanyak 37 orang dari responden, sisanya kesulitan dalam tajwid sebanyak $28,1 \%$ dan pengolahan suara sebanyak $22,9 \%$, sisanya memilih adab, nafas, dan lainnya.

Berangkat dari latar belakang ini, saya mencoba melakukan sebuah inovasi dengan mengembangkan media pembelajaran tilawatil quran dengan menerapkan Curve Audio Tracking. Curve Audio Tracking merupakan visualisasi irama nagham (lagu) dalam bentuk kurva, sehingga Qari atau Qariah akan 
memiliki informasi yang lebih rinci terkait irama nagham yang akan dibacakan.

\section{Dasar Teori}

Penelitian ini didukung dari berbagai teori yang berhubungan satu sama lain. Teori yang digunakan untuk memberikan kejelasan pada penelitian ini diantaranya teori Media Pembelajaran, teori Symbol System, dan teori Multimedia Pembelajaran.

\subsection{Media Pembelajaran}

Dalam dunia pendidikan kata 'media' disebut dengan media pembelajaran. Arsyad (2013: 10) menyampaikan bahwa media pembelajaran adalah segala sesuatu yang dapat digunakan untuk menyampaiakan pesan atau informasi dalam proses belajar mengajar sehingga dapat merangsang perhatian dan minat siswa dalam belajar.

Manfaat media pembelajaran disampaikan oleh Daryanto (2013:5) bahwa proses belajar mengajar hakekatnya adalah proses komunikasi, penyampaian pesan dari pengantar ke penerima. Dalam proses belajar terdapat pesan yang hendak disampaikan. Pesan tersebut dapat berupa informasi yang mudah diserap oleh penerima, namun juga dapat berupa infomrasi yang abstrak atau sulit untuk diterima. Ketika pesan yang disampaikan tidak dapat diterima oleh penerima maka diperlukan solusi yang dapat mengantarkan pesan tersebut. Media merupakan sarana atau alat yang digunakan untuk mengantarkan pesan dari pengirim ke penerima pesan, dengan tujuan untuk mengingkatkan pemahaman penerima pesan tersebut.

Sudjana dan Rivai (2013: 2) menyampaikan bahwa media pembelajaran dapat meningkatkan hasil belajar siswa, yaitu:1) Pengajaran akan lebih menarik perhatian siswa sehingga dapat menumbuhkan motivasi belajar. 2) Bahan pelajaran akan lebih jelas maknanya sehingga dapat lebih dipahami oleh siswa, dan memungkinkan siswa menguasai tujuan pembelajaran lebih baik. 3) Metode mengajar akan lebih bervariasi, tidak semata-mata penuturan verbal melalui penuturan kata-kata oleh guru. Sehingga siswa tidak bosan, dan guru tidak kehabisan tenaga, apalagi bila guru mengjar untuk setiap jam pelajaran. 4) Siswa lebih banyak melakukan kegiatan belajar, sebab tidak hanya mendengarkan uraian guru, tetapi juga aktivitas lain seperti mengamati, melakukan, mendemonstrasikan, dan lain-lain.

\subsection{Teori Symbol System}

Teori sistem simbol pertama kali digagas oleh Salomon (1979) dan merupakan teori yang ditujukan untuk menjelaskan dampak media terhadap pembelajaran. Menurut Salomon, setiap media memiliki kemampuan untuk menyampaikan isi melalui sistem simbol tertentu. Lebih lanjut Salomon menyatakan bahwa efektivitas sebuah media bergantung pada kesesuaian dengan peserta didik atau pelajar, isi, dan tugas.

Salomon (1979) menyatakan bahwa sistem simbol media mempengaruhi perolehan pengetahuan dalam beberapa cara. Pertama, mereka akan menyoroti berbagai aspek konten. Kedua, mereka bervariasi sehubungan dengan kemudahan pengkodean ulang. Ketiga, elemen-elemen pengkodean khusus dapat menyelamatkan pembelajar dari elaborasi mental yang sulit dengan terbuka menggantikan atau menguraikan elaborasi spesifik. Keempat, sistem simbol berbeda sehubungan dengan seberapa banyak pemrosesan yang mereka minta atau izinkan. Kelima, sistem simbol berbeda sehubungan dengan jenis proses mental yang mereka sebut untuk pengodean ulang dan elaborasi.

Fritz (1952) mengemukakan bahwa simbol diwujudkan dalam gambar, bentuk, gerakan, suara, atau benda yang mewakili suatu gagasan. Simbol yang paling umum ialah tulisan, yang merupakan simbol kata-kata dan suara. Simbol dapat merupakan benda sesungguhnya, simbol dapat berupa warna atau pola.

\subsection{Multimedia Pembelajaran}

Dalam merancang media pembelajaran hendaknya dirancang dengan mengikuti cara belajar manusia. Mayer (2009) menyebutkan sepuluh prinsip desain multimedia untuk dapat meningkatkan pemahaman dan kemampuan belajar siswa.

1. Prinsip Multimedia, siswa bisa belajar lebih baik dari kata-kata dan gambar-gambar daripada belajar dari kata-kata saja.

2. Prinsip Keterdekatan Ruang, siswa bisa belajar lebih baik saat kata-kata tercetak dan gambargambar yang terkait disajikan saling berdekatan daripada disajikan saling berjauhan.

3. Prinsip Keterdekatan Waktu, siswa bisa belajar lebih baik jika kata-kata ternarasikan dan gambargambar yang terkait (animasi atau video) disajikan pada waktu yang sama (simultan).

4. Prinsip Koherensi, siswa bisa belajar lebih baik jika hal-hal ekstra disisihkan dari sajian multimedia.

5. Prinsip Modalitas, siswa bisa belajar lebih baik dari animasi dan narasi (kata yang terucapkan) daripada animasi dan kata tercetak di layar.

6. Prinsip Redundansi, siswa bisa belajar lebih baik dari gambar dan narasi daripada dari gambar, narasi, dan teks tercetak di layar.

7. Prinsip Perbedaan Individual, pengaruh desain lebih kuat terhadap siswa berpengetahuan rendah daripada siswa berpengetahuan tinggi.

8. Prinsip Personalisasi, siswa bisa belajar lebih mudah dengan multimedia yang menggunakan 
gaya percakapan dalam narasi daripada gaya formal.

9. Prinsip Segmentasi dan Prinsip Pra-latihan, siswa bisa belajar lebih mudah jika materi pelajaran yang besar dipecah menjadi segmen-segmen kecil.

10. Prinsip Sinyal, siswa belajar lebih baik ketika kata-kata, diikuti dengan cue, highlight, kurva, penekanan yang relevan terhadap apa yang disajikan.

\section{Metodologi}

Pendekatan yang digunakan dalam penelitian ini adalah metode penelitian dan pengembangan (Research \& Development).

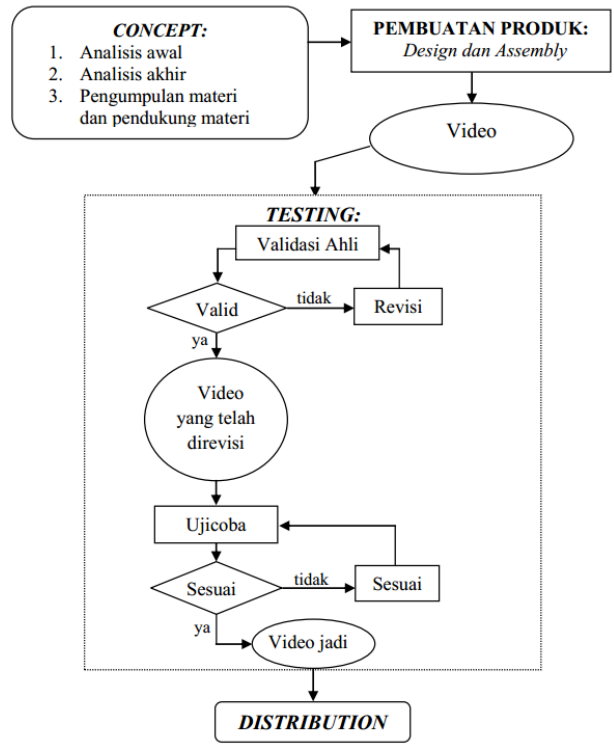

Gambar 3.1 Prosedur Pengembangan

Model pengembangan pada penelitian ini menggunakan model pengembangan Multimedia Development Life Cycle (MDLC). Menurut Sutopo (2003: 32) model ini mempunyai langkah-langkah yaitu : (a) Concept, (b) Design, (c) Material Collecting, (d) Assembly, (e) Testing, (f) Distribution.

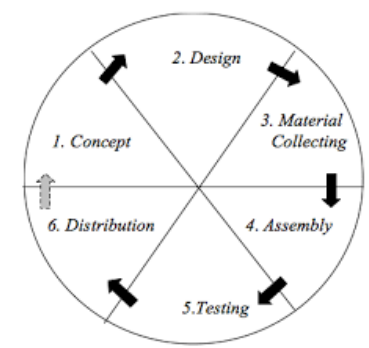

Gambar 3.2 Model Pengembangan MDLC

Sasaran penelitian ini adalah masyarakat umum yang beragama Islam berusia minimal 13 Tahun.
Teknik pengumpulan data pada penelitian ini adalah menggunakan kuesioner dengan menggunakan skala likert dan skala guttman. Skala Likert digunakan pada uji kelayakan responden untuk mengukur persepsi responden terhadap media pembelajaran, sedangkan skala Guttman digunakan pada uji kelayakan Ahli Media dan Ahli Materi untuk mendapat jawaban tegas terhadap media pembelajaran. Adapun teknik analisis data pada penelitian ini adalah sebagai berikut

Persentase kelayakan $(\%)=\frac{\text { Skor } \text { yang diobservasi }}{\text { Skor yang diharapkan }} \times 100 \%$ (1)

Persentase bisa digunakan untuk menetapkan status yang akan disajikan dari persentase tersebut. Tabel skala persentase menurut Arikunto (2009:35) adalah sebagai berikut:

Tabel 3.1 Skala Presentase

\begin{tabular}{|c|c|}
\hline $\begin{array}{c}\text { Persentase } \\
\text { Pencapaian }\end{array}$ & Interpretasi \\
\hline $81-100 \%$ & Sangat Layak \\
\hline $61-80 \%$ & Layak \\
\hline $41-60 \%$ & Cukup \\
\hline $21-39 \%$ & Kurang Layak \\
\hline$<21 \%$ & Sangat Tidak Layak \\
\hline
\end{tabular}

\section{Hasil dan Analisis}

Berdasarkan prosedur pengembangan yang telah dikemukakan, dalam pengembangan media pembelajaran berbasis video dengan menerapkan Curve Audio Tracking ini diketahui hasilnya sebagai berikut :

\subsection{Hasil Pengembangan Produk}

Pengembangan media pembelajaran berbasis video dengan menerapkan Curve Audio Tracking ini dilakukan melalui beberapa tahapan, yaitu :

1. Tahap Pembuatan Konsep yang meliputi analisis awal, analisis akhir, dan pengumpulan materi. Analisis awal dilakukan untuk mengetahui permasalahan yang terjadi pada masyarakat untuk mempelajari tilawatil quran. Hasil yang didapat pada analisis awal ini kemudian dijadikan dasar untuk pengembangan produk media pembelajaran tilawatil quran. Setelah melakukan analisis awal, dapat diketahui bahwa sebagian besar masyarakat memilih internet untuk mempelajari tilawatil quran dan aspek yang paling sulit untuk mempelajari tilawatil quran adalah irama nagham (lagu). Setelah dilakukan analisis awal, penelitian dilanjutkan dengan menganalisa kebutuhan baik itu kebutuhan materi atau media. 
2. Tahap Pembuatan Produk, yang meliputi design, dan assembly. yang dilakukan pada tahap ini adalah membuat Desain wireframe sebagai rancangan tampilan yang akan dibuat, pengumpulan materi dari rekaman suara tilawah sekaligus menganalisa nagham dan tingkatannya untuk kebuhan materi yang akan disajikan, kemudian dilanjutkan dengan membuat media pembelajaran untuk menjadi produk yang akan di uji coba.

3. Tahap Uji Coba, Tahap ini adalah tahap di mana media pembelajaran di uji coba. Tahap ini diperiksa oleh Ahli Media, Ahli Materi, dan Responden untuk memastikan bahwa media pembelajaran ini sudah sesuai dan layak digunakan sebagai media pembelajaran tilawatil quran;

4. Tahap Distribusi, Tahap ini adalah tahap di mana media pembelajaran tilawatil quran yang sudah dibuat di ekspor dari file project Adobe Premiere Pro (.prproj) menjadi file Video (.mp4) yang kemudian dapat disebarluaskan melalui Internet di berbagai platform video online.

\subsection{Kelayakan Produk}

Hasil uji coba media pembelajaran tilawatil quran berbasis video ini dilakukan terhadap tiga orang Ahli Media, tiga orang Ahli MateriKemudian 25 responden yang berasal dari masyarakat umum di berbagai usia. Hasil validasi Ahli Materi dan Ahli Media kemudian dijadikan dasar kelayakan media pembelajaran untuk diujicobakan di lapangan. Hasil tersebut diukur dengan skala persentase kelayakan menurut Arikunto (2013).

\section{Tabel 4.1 Validasi Ahli Media}

\begin{tabular}{|l|l|c|c|c|}
\hline \multirow{2}{*}{ No. } & \multirow{2}{*}{ Ahli Media } & \multicolumn{2}{|c|}{ Penilaian } & \multirow{2}{*}{ Kategori } \\
\cline { 3 - 4 } & & Tidak & Setuju & \\
\hline 1. & $\begin{array}{l}\text { Hamidilah } \\
\text { Ajie, S.Si., } \\
\text { M.T }\end{array}$ & 0 & 10 & Layak \\
\hline 2. & $\begin{array}{l}\text { Bambang } \\
\text { Prasetya Adhi, } \\
\text { S.Pd., } \\
\text { M.Kom. }\end{array}$ & 0 & 10 & Layak \\
\hline 3. & $\begin{array}{l}\text { Fandy Septia } \\
\text { Anggriawan, } \\
\text { S.Pd., M.Pd.T }\end{array}$ & 0 & 10 & Layak \\
\hline
\end{tabular}

Tabel 4.2 Validasi Ahli Materi

\begin{tabular}{|l|c|c|c|c|}
\hline \multirow{2}{*}{ No. } & \multirow{2}{*}{ Ahli Materi } & \multicolumn{2}{|c|}{ Penilaian } & \multirow{2}{*}{ Kategori } \\
\cline { 3 - 4 } & & Tidak & Setuju & \\
\hline
\end{tabular}

\begin{tabular}{|l|l|c|c|c|}
\hline 1. & $\begin{array}{l}\text { Rizki } \\
\text { Kurniawan, } \\
\text { S.Ag }\end{array}$ & 0 & 10 & Layak \\
\hline 2. & Iswandi, S.Pd & 0 & 10 & Layak \\
\hline 3. & $\begin{array}{l}\text { Nashoikhul } \\
\text { Ibad }\end{array}$ & 0 & 10 & Layak \\
\hline
\end{tabular}

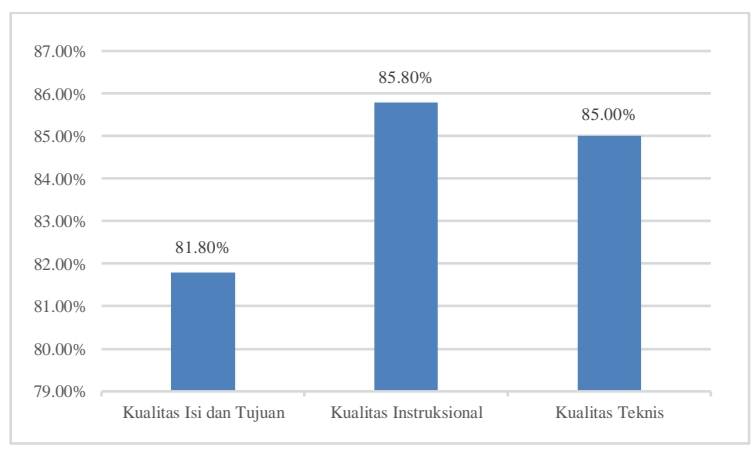

Gambar 4.1 Hasil Uji Coba Responden

\subsection{Pembahasan}

Produk akhir yang dihasilkan dari penelitian ini adalah media pembelajaran tilawatil quran berbasis video dengan menerapkan Curve Audio Tracking. Hasil dari Tahap Uji Coba adalah media pembelajaran telah dinyatakan layak oleh ketiga Ahli Media dan Ahli Materi dengan beberapa catatan dan saran didalamnya. Setelah itu dilakukan Uji Kelayakan untuk mengetahui jawaban dari responden. Hasil yang didapat dari Uji Kelayakan ini adalah media tersebut termasuk dalam kategori Sangat Layak dengan skor $84,3 \%$ menurut tabel persentase Arikunto (2013).

Media pembelajaran ini memiliki keunggulan dibandingkan media pembelajaran yang ada, diantaranya: (1) Media pembelajaran menyajikan konten secara lengkap, (2) Media pembelajaran dapat diakses tanpa terikat ruang dan waktu, (3) Media pembelajaran dapat memvisualisasikan irama Nagham (lagu) yang dianggap paling sulit.

Setelah melalui semua tahapan di atas dan telah dinyatakan layak baik dari Ahli Media, Ahli Materi, dan Responden. Maka media pembelajaran tilawatil quran berbasis video dengan menerapkan Curve Audio Tracking ini dikemas dalam bentuk file .mp4 yang diunggah pada platform video online sehingga video ini bisa diakses dimana saja dan kapan saja.

\section{Kesimpulan dan Saran}

Berdasarkan hasil penelitian dan pembahasan, maka dapat disimpulkan beberapa hal berikut ini:

1. Proses perancangan media pembelajaran tilawatil quran berbasis video dengan menerapkan Curve Audio Tracking telah 
berhasil dengan melakukan konversi suara menjadi keyframe.

2. Media pembelajaran yang dihasilkan berupa video dengan format .mp4 dengan resolusi 1280x720 (16:9).

3. Penilaian kelayakan media pembelajaran tilawatil quran berbasis video dilakukan oleh tiga Ahli Media, tiga Ahli Materi, dan Responden yang terdiri dari 25 orang dengan usia yang berbeda.. Hasil Uji Coba dan Uji Kelayakan ini mendapat hasil media pembelajaran tilawatil quran berbasis video dengan menerapkan Curve Audio Tracking ini dinyatakan Sangat Layak untuk dikembangkan dan disebarluaskan.

Berdasarkan penelitian yang telah dilakukan, maka berikut ini beberapa saran yang hendak disampaikan

1. Lembaga Pendidikan Al-Quran hendaknya menggunakan media pembelajaran tilawatil quran untuk mendukung pembelajaran yang ada di kelas.

2. Perbanyak media pembelajaran tilawatil quran yang dapat diakses menggunakan Internet.

Bagi peneliti yang tertarik untuk mengembangkan media pembelajaran yang serupa, hendaknya materi-materi yang telah ada pada media pembelajaran ini dikembangkan dan ditambahkan dengan materi-materi yang belum tercakup.

\section{Daftar Pustaka:}

Arsyad, Azhar. (2013). Media Pembelajaran. Jakarta: Raja Grafindo Persada.

Arikunto, Suharsimi (2009). Prosedur Penelitian Suatu Pendekatan Praktik. Edisi Revisi. Jakarta : Rineka Cipta.

Arikunto, Suharsimi (2013). Prosedur Penelitian : Suatu Pendekatan Praktik. Jakarta : Rineka Cipta

B, Fritz, Dorothy. (1952). The Use of Symbolism in Christian Education. United States of America : McmIXI W. L. Jenkins.

Daryanto. (2013). Media Pembelajaran Perannya Sangat Penting Dalam Mencapai Tujuan Pembelajaran. Yogyakarta: Gava Media.

Mayer, Richard E. (2009). Multimedia Learning. Yogyakarta : Pustaka Pelajar

Salomon, G. (1979). Interaction of Media, Cognition, and Learning. San Francisco: Jossey-Bass.

Sudjana, Nana dan Rivai, Ahmad. (2013). Media Pengajaran. Bandung: Sinar Baru Algensindo Offset.

Sutopo, Ariesto Hadi. (2003), Multimedia Interaktif dan Flash, PT Graha Ilmu. Yogyakarta. 